\title{
NEWS AND ANNOUNCEMENTS
}

\section{ADSA Member News ...}

New Homepage for Journal of Dairy Science ${ }^{\circledR}$ and Updated Contact Info

ADSA members can now access the Journal of Dairy Science via Elsevier's HealthConnect platform beginning with this issue. Go to http://www.journalofdairy science.org/ today to activate your subscription and access the journal on its new homepage.

Beginning in January 2010, Elsevier Customer Service will be handling questions related to online journal access, account activation, and print issue delivery. If you have questions about account activation and online access, contact JournalsOnlineSupport-usa@elsevier. com. If you have questions about print delivery and missing issues, contact JournalCustomerService-usa@ elsevier.com. If you have specific questions about your account, contact our society coordinator at Elsevier: Julie McNutt, j.mcnutt@elsevier.com; 215-239-3684.

For general ADSA questions, contact Vicki Paden, ADSA administrative assistant, by e-mail: vickip@ assochq.org or by phone: 217-356-5146 ext. 110, or Cara Tharp, ADSA executive assistant, by e-mail: carat@assochq.org or by phone: 217-356-5146 ext. 141 .

For journal policy questions, contact Susan Pollock, managing editor for JDS, by e-mail: susanp@assochq. org or phone: 217-356-3182 ext. 152. For JDS style and form questions and manuscript submission requirements, contact a technical editor by e-mail: journals@ assochq.org; and for Manuscript Central and JDS offprint questions, contact Jeremy Holzner by e-mail: jeremyh@assochq.org.

\section{ADSA ${ }^{\circledR}$ Global Partner Program}

ADSA is pleased to introduce e-Membership: Available only through ADSA Global Partner organizations, this electronic membership was designed for members of organizations who have an interest in dairy science, but may not have the time or budget to attend ADSA's annual meeting, or cost-justify full membership in ADSA due to a different area of specialization. The ADSA e-Membership rate is US $\$ 55$, a $50 \%$ discount from ADSA professional membership dues. ADSA eMembers receive

- Electronic access to the Journal of Dairy Science ${ }^{\circledR}$, (and a paper copy, if desired, for an additional fee);
- Access to a treasure trove of synchronized symposia recordings (currently 65 recorded symposia from 2003 to 2009, with more added each year);

- Access to searchable Joint Annual Meeting abstracts for 1998-2009, with more added each year, plus ADSA annual meeting abstracts from 19351997, and ADSA divisional meeting abstracts;

- The opportunity to subscribe to S-PAC ${ }^{\mathrm{TM}}$ (Searchable Proceedings of Animal Conferences) at the ADSA member rate.

\section{Upcoming Meetings ...}

Fifth IDF International Mastitis Conference 2010, March 21-24, 2010, Christchurch Convention Centre, New Zealand. Hosted by the New Zealand Veterinary Association Foundation for Continuing Education, VetLearn, and held only once every 5 years, the International Mastitis Conference offers a unique opportunity to report on innovative research and other advances in the understanding of mastitis research and extension. The opportunities for putting forward your research and views to industry leaders and your peers both locally and globally, as well as collaboration and networking with your peers will be invaluable and we encourage early submission. Visit www.idfmastitis2010. com for more information.

Nineteenth Discover Conference on Food Animal Agriculture: Key Issues in the Sustainability of the Dairy Industry, May 11-14, 2010, Brown County Inn, Nashville, Indiana.

Ninth World Congress on Genetics Applied to Livestock Production, August 1-6, 2010, Leipzig, Germany. The congress is the premier meeting point for scientists involved in genetic improvement of livestock around the world. Much has changed in the field of applied livestock genetics over the past 50 years and certainly over the last 35 years since the first WCGALP was held in Madrid, Spain, in 1974. Abstract submission deadline is February 28, 2010; early bird registration deadline is January 31, 2010, and regular registration is open from February 1 through May 31, 2010. Visit www.wcgalp2010.org for more information. 


\section{Positions Available . . .}

The deadline for the submission of position announcements for publication in the Journal of Dairy Science is the 25th day of the month, two months preceding the month of issue. For example, ads submitted by May 25 will be printed in the July issue of the journal.

Fees for ads are based on membership in the American Dairy Science Association or the American Society of Animal Science. For members, the flat fee is $\$ 150$; for others, $\$ 250$. We do not accept display ads. Ads from agencies are not commissionable.

Position announcements should be electronically submitted, using the form on the Federation of Animal Science Societies (FASS) Web site, http://www.fass.org/job.asp, for publication in the printed version of the journal and online at the FASS Job Resource Center. Ads that appear in the printed version will automatically be posted online at no extra charge. Ads that are received past the deadline will appear only on the Web site.

If electronic submission is impossible, ads can be e-mailed to fass@assochq.org. Ads should be formatted as a single paragraph; complete sentences should be used. Advertisers will receive an invoice after the ad is posted or published; those who meet print publication deadline will receive a tearsheet with the invoice.

For more job placement announcements, please see the FASS Job Resource Center at www.fass.org/

- Dairy Development Director. DeLaval is currently looking for a dairy expert ready to take on the challenges to provide valuable inputs to the process of developing the next generation of solutions for dairy farmers (both equipment and aftermarket consumables). These solutions will have a strong emphasis on providing tools to customers that enable them to farm smarter and also in a more sustainable way. The vacancy is based at DeLaval headquarters located in Tumba, Sweden. The role offers an opportunity to make an impact on the future of dairy production. Working closely with the group management ensures a high profile and a prioritized position within the company.

The ideal candidate has a minimum degree equal to a $\mathrm{PhD}$ in animal husbandry/physiology/dairy herd management/veterinary medicine; practical experience of running a dairy farm; business experience from a field related to the dairy industry; and is passionate in regards to developing dairy production both on a technical and theoretical level. Minimum requirements include practical agriculture including milking and dairy herd management; a basic university degree (wide knowledge) and $\mathrm{PhD}$ in animal husbandry/physiology/ dairy herd management/veterinary medicine (deep knowledge); practical training or studies abroad; and some years of practical experience following theoretical education.

The candidate should have a Scandinavian language as his/her mother tongue, English or fluency in English, and an additional two languages. The candidate should have special interest in building-up/establishing/expanding an international network of scientist/researchers/universities/institutes; interest in aspects of the whole chain of food production from farm to table; interest in cooperating with international organizations or special bodies like EU, IDF, ISO, ICAR and the like; be service minded, toward both internal and external customers; have ambitions to become "number one" within his/her competence area; and have a commercial outlook. In addition, the candidate will have excellent skills in cooperating with people and organizations; have skill in communicating and presenting oral and written papers; be capable of driving key/strategic issues for the company; be able to assist in setting standards; and able to finish committed activities/projects in time. The ideal candidate will be visionary, creative, and innovative; interested in building-up "world's best" competence in one or more of the key competence areas of DeLaval; and able to manage people.

If you feel this position would be of interest to you, please do not hesitate to submit an application at www. delaval.com or contact HR Manager Andreas Sjöström on +46734131 436 (phone) or andreas.sjostrom@ delaval.com (e-mail).

DeLaval is dedicated to ensuring reliably profitable dairy farming. The organization is globally focused on satisfying customers' farming requirements at local level. Business is aligned towards being the dairy farmer's first choice whenever he or she has a need. The DeLaval mission supports this vision by utilizing premium resources, technical expertise, and service to drive progress in milk production. This drive is acutely focused on providing trusted, long-term, and highly rewarding partnerships to customers in over 115 countries.

For more job position announcements, please see the FASS Job Resource Center at http:// www.fass.org/job.asp 